\title{
NEW ČEBYŠEV TYPE INEQUALITIES FOR DOUBLE INTEGRALS
}

\section{A. Guezane-Lakoud and F. Aissaoui}

Abstract. The aim of this paper is to establish new extension of the weighted Montgomery identity for functions of two independent variables, then obtain new Čebyšev type inequalities.

Mathematics subject classification (2010): 26D15, 26D20.

Keywords and phrases: Čebyšev type inequalities, Pečarić's extension, Montegomery identity.

\section{REFERENCES}

[1] F. Ahmad, N. S. Barnett, S. S. Dragomir, New weighted Ostrowski and Cebysev type inequalities, Nonlinear Analysis 71 (2009), 1408-1412.

[2] N. S. BARNETT, S. S. DRAGOMIR, An Ostrowski type inequality for double integrals and applications for cubature formulae, Soochow J. Math. 27, 1 (2001), 1-10.

[3] K. Boukerrioua, A. Guezane-Lakoud, On generalization of Čebyšev type inequalities, J. Inequal.Pure and Appl. Math. 8, 2 (2007), Art 55.

[4] P. L. ČEBYSEV, Sur les expressions approximatives des intégrales définies par les autres prises entre les mêmes limites, Proc. Math. Soc. Charkov. 2 (1882), 93-98.

[5] S. S. Dragomir, P. Cerone, N. S. Barnett, J. Roumeliotis, An inequality of the Ostrowski type for double integrals and applications for cubature formulae, Tamsui Oxf. J. Math. Sci. 16, 1 (2000), 1-16.

[6] D. S. Mitrinović, J. E. PeČArić, A. M. FinK, Inequalities for Functions and Their Integrals and Derivatives, Kluwer Academic Publishers, Dordrecht, 1994.

[7] B. G. PachPatte, On Čebysev-Gruss type inequalities via Pecaric's extention of the Montgomery identity, J. Inequal. Pure and Appl. Math. 7, 1 (2006), Art 11.

[8] B. G. PACHPATte, New inequalities of Čebysev type for double integrals, Demonstratio Mathematica XI, 1 (2007), 43-50.

[9] J. E. PEČARIĆ, A. VuKelić, Montgomery's identities for function of two variables, J. Math. Anal. Appl. 332 (2007), 617-630.

[10] J. E. PeČARIĆ, On the Čebysev inequality, Bul. Dti. Tehn. Inst. Politehn. Train Vuia Timisora 25 (39), 1 (1980), 5-9.

[11] M. Z. SARikaya, N. AKtan, H. Yildirimon, Weighted Cebysev-Gruss type inequalities on time scales, J. Math. Inequal. 2, 2 (2008), 185-195. 